\title{
PROBLEMS IN SPORTS ACTIVITIES POSSIBILITIES OF USING TECHNOLOGIES
}

\author{
Zulfiya Abubakirovna Dehkambaeva
}

Associate Professor, Ph.D., "Pedagogy And Psychology", Specialists In Physical Education And Sports Institute Of Retraining And Advanced Training, Uzbekistan

\section{ABSTRACT}

This article discusses the possible issues while doing sport activities with technologies and finding solutions to deal with that accrued problems. Additionally in this article here are shown body parts and its diagrams to give some understandings to the learners. Also students being taught to make a goal in is his career and life as well

KEYWORDS: - Ability, children and adolescents, tactical thinking, body parts, physical fitness, goal.

\section{INTRODUCTION}

One of the most important tasks today is the social formation of young athletes, their achievement of physical maturity, the active development of important individual, personal and professional qualities. It is important to increase the level of physical fitness, to acquire a system of special knowledge, skills and abilities, to develop the ability to cope with difficult situations in sports. Because an athlete who does not have the skills to get out of difficult situations, loses several times in competitions. An athlete who is able to get out of a difficult situation quickly will be able to adapt quickly and solve a difficult situation. That is why we need to develop the skills of children and adolescents to get out of difficult situations, starting from sports schools.
A new image that has been studied in Uzbekistan in recent years in the process of modernization of education is an effective, convenient method of teaching. At the same time, the study of innovative pedagogical technologies of education is important.

Innovative pedagogical technologies are part of the problem-based learning technologies. Problem-based learning technologies began to be studied in the 60 s of the twentieth century, based on the idea that "thinking begins with a problem situation." We strive to develop such qualities as In addition, it is very important to develop tactical thinking in athletes in the game.

Not only the content of the lessons, but also the educational technologies used play an important role in the formation of a person with the above qualities. Application of problem-based learning technology in sports in order to teach problem- 
CURRENT RESEARCH JOURNAL OF PEDAGOGICS 2(11): 220-225,

November 2021 DOI: https://doi.org/10.37547/pedagogics-crjp-02-11-40

ISSN 2767-3278

(C)2021 Master Journals

Crossref do: 81 Google

Accepted 25 $5^{\text {th }}$ November, 2021 \& Published 30th November, 2021

solving skills. This is because in the process of problem-solving, both the coach and the young athlete constantly test their intellectual, physical and spiritual abilities in order to study and solve practical problems. The skills and abilities acquired in this process lead to the formation of the necessary qualities.

Throughout his life, a person is constantly confronted with many urgent problems and tasks. Such problems and difficulties mean that there are many unknown and hidden elements in the world around us that we do not know yet. To know them, it is necessary to have a deeper understanding of the world, to discover new processes taking place in the universe, to study in depth the nature of the relationship between people and things.

It is necessary for a person to be creative, independent and thoughtful, and the process of thinking begins with a problematic situation. A problem situation is a mental difficulty, a conflict situation, and by developing students' ability to think, they develop the ability to think.

The role of the young athlete's independence in the problem-based learning process is much more effective than comparing it to reproductive learning methods. The purpose of problem-based learning in sports is to prepare young athletes for the competition process and to develop the skills to solve problem situations encountered in competitions.

N. Azizkhujaeva described the meaning of a problematic situation as follows: that is, a problematic situation is a dialectical contradiction between information, knowledge, new evidence, events, and situations that the reader has acquired in order to understand them. These contradictions (misunderstandings) serve as a driving force for the acquisition of creative knowledge.

The problem situation in the learning process is characterized by the following:

- Unknown novelty for young athletes;

- $\quad$ solve problems themselves;

- try to study the misunderstandings that arise due to personal interests and needs;

- They know what is unknown, understand its meaning and try to solve it.

It is also important for the teacher to have a clear understanding of his / her role in the organization and conduct of problem-based learning. The coach should not give young athletes a ready mind, but should give them the right direction in their search. Young athletes should aim to gain an independent opinion by analyzing events, news, events and various facts that occur in sports, competitions and everyday life. It also provides an opportunity for children and adolescents to deepen their research activities, knowledge and skills in a challenging school of sports, and to make a significant positive impact on their perceptions of changes in the environment.

In the coaching system, young athletes organize their research activities in such a way that their attention is focused on solving problems and shortcomings, independent analysis of various information, finding solutions, summarizing and drawing conclusions, and drawing conclusions. need. As a result, young athletes are able to think independently, develop skills, set new goals, learn new ways of thinking, and develop the ability to think. In the process of problem-based learning, young athletes are able to study learning materials in difficult situations, independently analyze relevant information, make predictions about the given learning problems, solve them in a way that proves them, and develop the learning process.

The activity of the coach in problem lessons, first of all, to identify learning problems based on the content of the topic, to create a system of 
CURRENT RESEARCH JOURNAL OF PEDAGOGICS 2(11): 220-225,

November 2021 DOI: https://doi.org/10.37547/pedagogics-crjp-02-11-40

ISSN 2767-3278

(C)2021 Master Journals

Crossref do: 81 Google

Accepted 25th November, 2021 \& Published 30 ${ }^{\text {th }}$ November, 2021

problem situations, to set learning problems for young athletes at a high methodological level, to solve learning problems in sports.

Problem-based learning technologies include "Brainstorming", "Networks", "Boomerang", "Scarab", "Resume", "Black Box", "6 x 6 x 6", "Synectics," Functional-Useful Analysis "," ARIZTRIZE », "Why? », "Where? » and Case Study methods. For example, in the "Why?" Method, we asked, "Why did the young athlete fail to master a particular skill?" The questions and answers to the problem are written.

One of the most effective ways to develop tactical thinking is problem-based learning technology. Case technology is one of its most effective options. It is carried out through a special collection of teaching materials (cases) for children. In this case, the teaching materials are developed in an organized manner, using a variety of factors and methods that are suitable for the learning process. Although case technologies are used at all stages of implementation, they are implemented in conjunction with other educational technologies and do not require special support.

Case technology is a method of active problemsituational analysis based on the solution of specific situational tasks. A distinctive feature of the case technology method is the creation of a problematic situation based on real-life facts.

The purpose of using the method is to analyze the situation and develop solutions to it, based on the collaborative activities of a group of students; At the end of the process, the algorithms presented in the context of the problem are evaluated and the best one is selected.

Case is an interactive technology that combines a single set of information, based on problembased learning. Case-technology, which is one of the traditional methods of teaching, involves the development of motor skills in children in physical education, independent decisionmaking, finding the right solutions to problems. This method involves the demonstration of creativity, creative approach and creativity on the part of students. Not only the end result but also the process of acquiring knowledge is important. An example is case study technology, which aims to teach children the best techniques in tennis. - to teach students to analyze the problems that arise in the implementation of the program.

Assignment: One of the main tasks of a tennis coach is to explain to children the practical application of biomechanics, the analysis of specific movements in the chain of coordination of strokes in tennis.

Words like "feel the time" and "rhythm" are words that are used over and over again by the coach, and are meant to improve the basic quality of percussion mechanics given by the player. Its solution requires knowledge of the principles of coordination sequence.

The sequence of coordination means "the transfer of a strong motion occurring in one part of the body that moves like a single-stranded ring to another" (Groppel.1984).

Optimal coordination of body parts means that the speed can be effectively transferred from one part of the body to another.

Body parts step by step 
CURRENT RESEARCH JOURNAL OF PEDAGOGICS 2(11): 220-225,

November 2021 DOI: https://doi.org/10.37547/pedagogics-crjp-02-11-40

ISSN 2767-3278

(C)2021 Master Journals

Crossref dof 81 Google

Accepted 25th November, 2021 \& Published 30 th November, 2021

Body parts

FEET

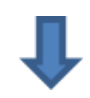

BACK

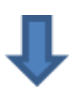

CHEST

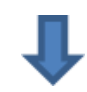

ARM / SHOULDER

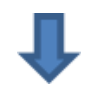

ELBOW

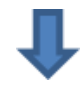

BONE
Biomechanics

KNEES

WAIST CIRCUIT

CHEST CIRCUMFERENCE

SHOULDER ROUND

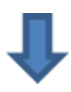

ELBOW ADJUSTMENT / PRONATION

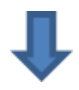

FLEXIBLE BONES

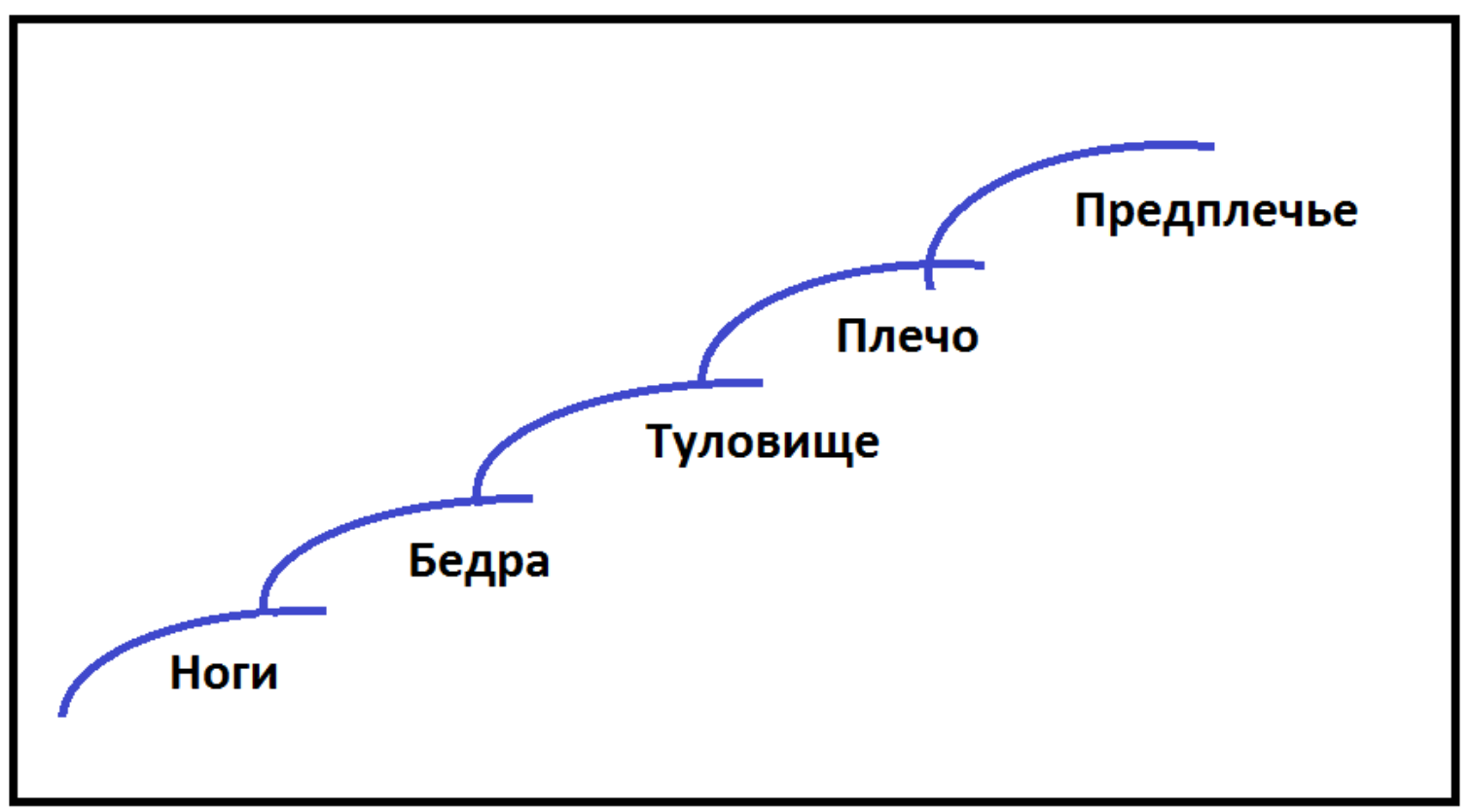


CURRENT RESEARCH JOURNAL OF PEDAGOGICS 2(11): 220-225,

November 2021 DOI: https://doi.org/10.37547/pedagogics-crjp-02-11-40

ISSN 2767-3278

(C)2021 Master Journals

\section{Crossref do) 8 Google}

Accepted 25 $5^{\text {th }}$ November, 2021 \& Published 30th November, 2021

Words inside the rectangle: legs, waist, torso, shoulders, wrists

Figure 1. Coordination sequence diagram.

The speed of the previous body parts is matched by its speed after the next, this speed acts as a general result. Thus, in the chain of coordination sequence, the forces continue to flow and coordinate from beginning to end, ideally, the tennis racket accelerates due to the combination of intensity. The interesting feature of the diagram is that it shows the position of the body parts during the stroke, one after the other, aimed at increasing the speed of the tennis racket in the "stair effect". The coordination chain is called the system of most body parts and is the multifaceted basis of optimal technique, because it determines the effectiveness of sports training with the following features:

- Increases strength.

- $\quad$ Strengthens control.

- Leaves fatigue.

- $\quad$ Prevents injury.

- In analyzing the effectiveness of the use of the coordination chain, attention should be paid to the following:

- The movement should start from the ground and go upwards.

- $\quad$ The movement must move from a large segment to a small one.

- The action must be taken in a timely manner and in an elevated manner.

\section{Assignment to the group}

There are 4 reasons related to the problem in the coordination chain, which leads to the injury of the player, his inability to control his movements, the inability to execute the blow with sufficient force.

The children are divided into four groups, and each group is given a separate task on the above situation that reflects the problem of coordination sequence.

In this way, any teacher who wants to use case-technology can, with familiarity with specific literature, identify specific learning situations and perform this task with sufficient skill. But the goal should not be to use exactly this educational technology. Situational analysis technologies are used in conjunction with learning objectives and tasks, taking into account the characteristics of the study group, children's interests and needs, level of competence, regulations and, in general, the application of case technology, many other factors determining its preparation and implementation and used to effectively implement its goals and objectives.

Thus, problem-based learning helps young athletes to effectively master their knowledge, skills and abilities systems and physical activities, to use their new skills effectively in future situations, to solve problems in sports competitions, to teach independent research, to gain creative experience and to develop problem-based learning opportunities. In general, problem-based learning technology in sports is a problem situation under the guidance of a coach, which means the organization of the educational process that allows young athletes to creatively acquire knowledge, skills and abilities and develop intellectual activity as a result of active independent work. Also, the essence of problem-based learning in sports is that the coach manages the cognitive activity of young athletes to create new problem situations in sports and to acquire new knowledge, skills and abilities by solving special tasks and problems. 
CURRENT RESEARCH JOURNAL OF PEDAGOGICS 2(11): 220-225,

November 2021 DOI: https://doi.org/10.37547/pedagogics-crjp-02-11-40

ISSN 2767-3278

(C)2021 Master Journals

Crossief do) 88 Google

Accepted 25th November, 2021 \& Published 30 ${ }^{\text {th }}$ November, 2021

\section{RefEREnCES}

1. Decree of the President of the Republic of Uzbekistan No. PF-4947 of February 7, 2017 "On the Action Strategy for further development of the Republic of Uzbekistan". Collection of Legislation of the Republic of Uzbekistan. - Number 6 (766). - Article 70. B. 25-151.

2. Resolution of the President of the Republic of Uzbekistan dated June 3, 2017 "On measures for further development of physical culture and mass sports"

3. Resolution No. PQ-3031. Collection of Legislation of the Republic of Uzbekistan. -
23 (783) -son. - Article 455 - P. 47-69.

4. Mirziyoyev Sh.M. Critical analysis, strict discipline and personal responsibility should be a daily rule of every leader. Report of the enlarged meeting of the Cabinet of Ministers on the main results of socio-economic development of the country in 2016 and the most important priorities of the economic program for 2017, January 14, 2017. - Tashkent: "Uzbekistan", 2017. - 104 p.

5. N.N.Azizxo'jaeva. Pedagogical technology and pedagogical skills. - T .: TDPU, 2003. 